\title{
Yara İyileştirme Özellikli Polimerlerin Yara Örtülerinde Kullanımı
}

\author{
Duygu ÜNER BAHAR*
}

\section{$\ddot{O} \mathbf{z}$}

Yara, vücutta bir dış etki ile oluşan, doku yapı ve bütünlüğünü bozan her türlü lezyondur. Yara tedavisinde uygulanacak yöntemin etkinliği, yara tipine uygun olarak seçilmesine bağlıdır. Doğru yöntem, doğru materyal ve yara örtüsü uygulama süresi seçimi yara iyileşmesi için kritik parametrelerdir. Bu makalede yara örtülerinde kullanılan iyileştirme özellikli polimerler doğal ve sentetik polimerler olmak üzere iki ana başlık altında toplanarak incelenmiştir.

Anahtar kelimeler: Yara tedavisi, doğal polimerler, sentetik polimerler, polimerik yara örtüleri, hasta refahı.

\section{Use of Wound Healing Polymers in Wound Dressings}

\begin{abstract}
Wound is any kind of lesion caused by an external effect on the body and disrupts tissue structure and integrity. The effectiveness of the method to be applied in wound treatment depends on the selection according to the type of wound. Choosing the right method, the right material and the appropriate exposure time of the wound are critical parameters for wound healing. In this article, the healing polymers used in wound dressings were classified under two main headings as natural and synthetic polymers.
\end{abstract}

Keywords: Wound treatment, natural polymers, synthetic polymers, polymeric dressings, patient welfare.

Derleme Makale (Review Article)

Geliş / Received: 09.01.2021 \& Kabul / Accepted: 31.03.2021

DOI: https://doi.org/10.38079/igusabder.857250

${ }^{*}$ Dr. Öğr. Üyesi, İstanbul Gelişim Üniversitesi, Sağllk Hizmetleri Meslek Yüksekokulu, Biyomedikal Cihaz Teknolojisi, İstanbul, Türkiye, E-posta: duner@gelisim.edu.tr ;

duygu.uner1@gmail.com ORCID https://orcid.org/0000-0003-3726-829X 


\section{Giriş}

Yara iyileşmesi birçok hücre tipini, çeşitli sitokinleri, büyüme faktörlerini ve bunlar arasındaki etkileşimi içeren oldukça karmaşık bir sistemdir. Hücre adezyonu, hücre göçü, hücre proliferasyonu, hücre farklılaşması ve apoptozis gibi aşamaları içerir. Sonuç olarak yara tamamen epidermis ile kaplanır ${ }^{1-4}$. Bu karmaşık iyileşme sisteminin doğru çalışabilmesi için medikal alanda kullanılan, vücut ile temas eden her malzemenin biyouyumlu olması esastır. Çünkü vücut yabancı bir madde ile karşılaştığında immun sistem devreye girerek tanımadığı bu malzemeyi vücuttan dışarı atmak için savaşır. Bunun sonucunda da malzeme vücut tarafından reddedilir ve iyileşme gerçekleşmez. Ĕ̆er kullanılan materyal kan ile temas halinde ise yara bölgesine önce iyonlar, proteinler ve trombositler gelir. Kullanılan materyal kan ile uyumlu olarak seçilmişse albümin yüzeye yapışarak bölgeyi pasifize eder. Böylece yüzeye gelen plateletler yüzeye yapışarak biyouyumluluk sağlanmış olur. Eğer biyouyumluluk yoksa bölgeye gelen trombositlerin yapısı bozulma göstererek bazı moleküllerin dışarı salınmasına neden olurlar. Bu salgı ile diğer hücreler de bölgeye göç ederek bölgede pıhtılaşma sağlanır ve trombus oluşturulur. Oluşan trombus da yüzeyden koparak emboliye neden olabilir. Bu durum bazı ilerlemiş doku hasarlarında ölüme neden olabilmektedir5. Kullanılan malzeme doku ile temas halinde ise bu materyalin yüzeyinde bulunan kimyasallar doku cevabını başlatır. Kan damarları ile bölgeye göç eden makrofajlar algıladıkları bu yabancı maddeleri fagosite ederek yok etmeye çalışırlar. Eğer bu olay oluşmadıysa malzeme çevresi fibroz bir doku ile sarılarak skar oluşumu sağlanır veya içinde fibroz doku büyümesi sağlanır. Kullanılan malzeme ile doku arasında şiddetli bir uyuşmazlık söz konusu ise tümör oluşumu, doku nekrozu gibi geri dönüşümü olmayan durumlar oluşabilmektedir. Bu nedenle yaraya uygun olarak seçilen malzemenin biyouyumlu olması hastanın genel sağlı̆̆ ve yaranın iyileşmesi için büyük önem taşımaktadır. Örneğin kronik yaralar 6-8 haftada tamamen iyileşmeyen ya da 4 haftada hiç iyileşme belirtisi göstermeyen yaralardır. Bu duruma sebep olan faktörler; intrensek (diyabet, venöz yetmezlik, kronik hastalık vb.) veya ekstrensek (Eksternal basınç, yetersiz beslenme vb.) faktörler ya da doğru olmayan tedavi yöntemi uygulanması, yanlış yara örtü materyali seçimi olabilir.

Günümüzde birçok yara bakım ürünü bulunmaktadır. Bunlar çok sayıda ve çok farklı özelliklere sahip modern yara bakımı ürünleridir. Kronik yaralar dahi uygun konvansiyonel tedavi yöntemleri ile de tedavi edilebilirler. Ancak bu malzemenin hastaya 
spesifik biyouyumluluğu esas olmalıdır. Aksi takdirde bu materyallerin kullanımı tedavi sürecini uzatır ve iyileşmeyi güçleştirir. Modern yara bakımı ürünleri ile ekonomik kayıpların, işgücü kayıplarının büyük ölçüde azaltılabildiği bilinmektedir. Modern tedavi ürünleri yara iyileşmesinin eksiklerini tamamlar ve iyileşmeyi hızlandırmaktadır.

İdeal bir yara örtüsünün sahip olması gereken özellikler; oksijen ve su buharı geçirgenliği, yaradan çıkan exudayı absorblama, yara yüzeyinde tutunma, yara yüzeyinden kolay ayrılma, antijenik veya mikrobik olmama, bakteriyel invazyonu engelleme, elastiklik, topikal ajanlara uygunluk, doku uygunluğu, kolay uygulanabilirlik, kolay sterilizasyon, ucuzluk olarak siralanabilmektedir5-8.

\section{Yara Örtülerinde Kullanılan İyileştirme Özellikli Polimerler}

Yara iyileşme mekanizması hücresel ve biyokimyasal bileşenlerin dışında, birçok enzimatik yolda doku yenilenmesi ve iyileşmesinde kilit rol oynamaktadır9,10. Bu nedenle bu karmaşık sistemi destekleyici ve süreci hızlandırıcı doğal ve sentetik polimer-jel benzeri yapılar (film, membran) kompozit, mikro/nano partiküller yara tedavi sürecinde ağırlıklı olarak kullanılmaktadır. Örneğin nanofibril membranlar yüksek yüzey genişlikleri ve yumuşaklıkları nedeniyle, terapötik ajanları taşımak ve iyileşmeyi hızlandırmak için büyük oranda kullanılabilirler. Diğer yandan biyouyumlu ve biyobozunur polimer scaffoldlar (doku iskeleleri), hücre ve biyolojik sinyallerle birleştirilerek dokuların yeniden yapılandırılması ve transplantasyon için geleneksel tedavi seçeneklerine alternatif olarak sunulmaktadırlar. $\mathrm{Bu}$ tip uygulamalar da tasarlanmış dokular olarak yara iyileşmesini hızlandırır. Bu nedenle doku yenilenmesi için uzun zamandır uygulanmaktadırlar. Yara iyileşme malzemesi olarak kullanılan ilk sentetik materyal metil selülozdur ${ }^{11}$. Bu tip sentetik malzemelerin hepsinde de ortak nokta yarayı dışsal faktörlerden fiziksel olarak koruma görevidir. Son 10 yıldır sprey, jel, köpük, film formlarda yara örtü malzemelerin kullanımı yaygınlaşmaktadır ve bu alanda malzeme geliştirmek için yapılan çalışmalar hız kazanmıştır ${ }^{12-14}$.

Yara tedavisinde kullanılan polimerleri elde edilişine göre doğal ve sentetik olarak iki sınıfta incelenebilmektedir, ancak içerdikleri malzemelere göre sınıflandırılması yapılmaktadır. En çok kabul gören sınıflandırma geleneksel örtüler, biyomalzeme bazlı örtüler ve yapay örtüler şeklindediri15,16.

Geleneksel örtüler: En sık kullanılan örtü yüksek absorpsiyon kapasiteli gaz, gaz-pamuk 
kompositidir. Hızlı debridasyon yapmasına karşın yara yüzeyinden de kolayca kayabilir. Bu nedenle kanama ve epitelyumda yeni hasarlara neden olabilirler. Bu örtülerden sızan eksudalar da enfeksiyon riskini arttırmaktadır. Ancak bu malzemeler en ekonomik örtülerdendir ${ }^{17}$. Geleneksel örtülere şu malzemeleri örnek verilebilir: \%o,5 kloroxidin asetat içeren parafin gazlı bezler, absorbent pamuk örtüler, petrol temelli gazlı bezler vb. Biyomalzeme temelli örtüler: Bu gruptaki en etkin uygulama allograftlardır. Ancak büyük yüzey kaplayan yaralar için donör yetersiz kalacağından kullanımı da kısıtlı kalmaktadır. Genellikle kollajen kaynaklı biyolojik yapılar kullanılır. Uygun donör bulunduğunda oldukça etkin sonuçlar alınabilmektedir, ancak uygulama maliyeti yüksektir. Bu tip örtüler de şu şekilde sınıflandırılmıştır: Allograft, ksenograft ve deri türevleri.

Yapay örtüler: Geleneksel ve biyomalzeme kaynaklı örtülerin stabilite sorunu ve enfeksiyon riski olduğundan kullanım alanları kısıtlı kalmaktadır. Bu nedenle bilim insanları daha etkili ve daha az riskli malzeme tasarımına yönelerek yapay örtüleri geliştirmişlerdir. Burada amaç daha ucuz, daha etkin ve daha uzun ömürlü örtü oluşturabilmektir. Birçok yara örtüsü yara için ideal mekanik özelliklere sahip olmasına karşın, yara ve yanık için farklı patofizyolojilerden dolayı farklılaştırılmak zorunda kalmıştır. Bu durum da her yara tipi için optimum malzeme seçimini kısıtlamakta ve farklılaştırmaktadır. İnflamasyon, doku yenilenmesi, fibrosis, koagülasyon gibi iyileşme faktörleri dikkate alınarak optimum şartları sağlayan bir örtü geliştirilebilmektedir ${ }^{18}$. Tablo 1'de en sık uygulanan yapay yara örtülerinin formu ve ana malzemesi yer almaktadır. 
Tablo 1. Yapay yara örtüleri formları ve içerikleri ${ }^{11}$

\begin{tabular}{|c|c|}
\hline Ürün Formu & Hammadde \\
\hline \multirow{8}{*}{ Film/membran } & Poliüretan \\
\hline & Polivinil klorür \\
\hline & Naylon Kadife \\
\hline & Poliviniliden klorür \\
\hline & Poliüretan hidrokolloid \\
\hline & Sentetik Elyaf + Alüminyum \\
\hline & Sentetik Elyaf + Metal \\
\hline & Aktifleştirilmiş odun kömürü \\
\hline \multirow{3}{*}{ Köpülk } & Formalize polivinil alkol \\
\hline & Poliüretan \\
\hline & Poly (dimetilsiloksan) \\
\hline \multirow[b]{2}{*}{ Jel } & Kalsiyum aljinat \\
\hline & $\begin{array}{l}\text { Assllı akrilamid ve hidroksietilmetakrilatlı } \\
\text { poliüretan }\end{array}$ \\
\hline \multirow{2}{*}{ Kompozit } & Poliprofilen film ve poliüretan köpük \\
\hline & Naylon kumaşlı silikon film \\
\hline \multirow{2}{*}{ Sprey } & Metakrilik asit etoksietilester \\
\hline & Polihidroksietilmetakrilat ve polietilen glikol \\
\hline
\end{tabular}

Yapay örtüleri hazırlamak için birçok polimer kullanılmaktadır. Bu çalışmada yara örtülerinde hammadde olarak en sık kullanılan polimerler ele alınmıştır. Bu polimerle oluşturulan çeşitli yara örtülerinin iyileştirme üzerine etkinliği üzerinde durulmuştur.

\section{Doğal Polimerler}

Yara örtülerinde en sık kullanılan ve yara iyileşmesine katkısı olduğu düşünülen doğal kaynaklı polimerler kitin/kitosan, kollajen, aljinik asit, hyaluronik asit, fukoidan, polyn-asetil glukozamin olarak sıralanmaktadır.

\section{Kitin/Kitosan}

Kitosan, kitinin deasetilasyonu ile üretililr. $\beta$-(1-4)-D-glikozamin'in ve N-asetil-Dglikozamin'in rastgele bağlanması ile oluşturulmuş lineer bir polisakkarittiri ${ }^{19}$. Yara üzerinde hemostatik etkisi nedeniyle pek çok yara örtüsünde tercih edilmektedir. 
İyileşme ile ilgili erken faz reaksiyonunu arttırdığı ve fibroblast formasyonunu hızlandırdığı düşünülmektedir ${ }^{20}$. Kitosan; film, hidrojel, fibril, mikro/nanopartikül, toz formda hazırlanabilmektedir. Düşük toksisite özelliği, biyobozunur ve biyouyumlu olduğundan dolayı kitosanın biyomedikal kullanımı da giderek artmaktadır. Şekil ı'de kitin-kitosan yapısı gösterilmiştir.

Şekil 1. Kitin-kitosan yapısı

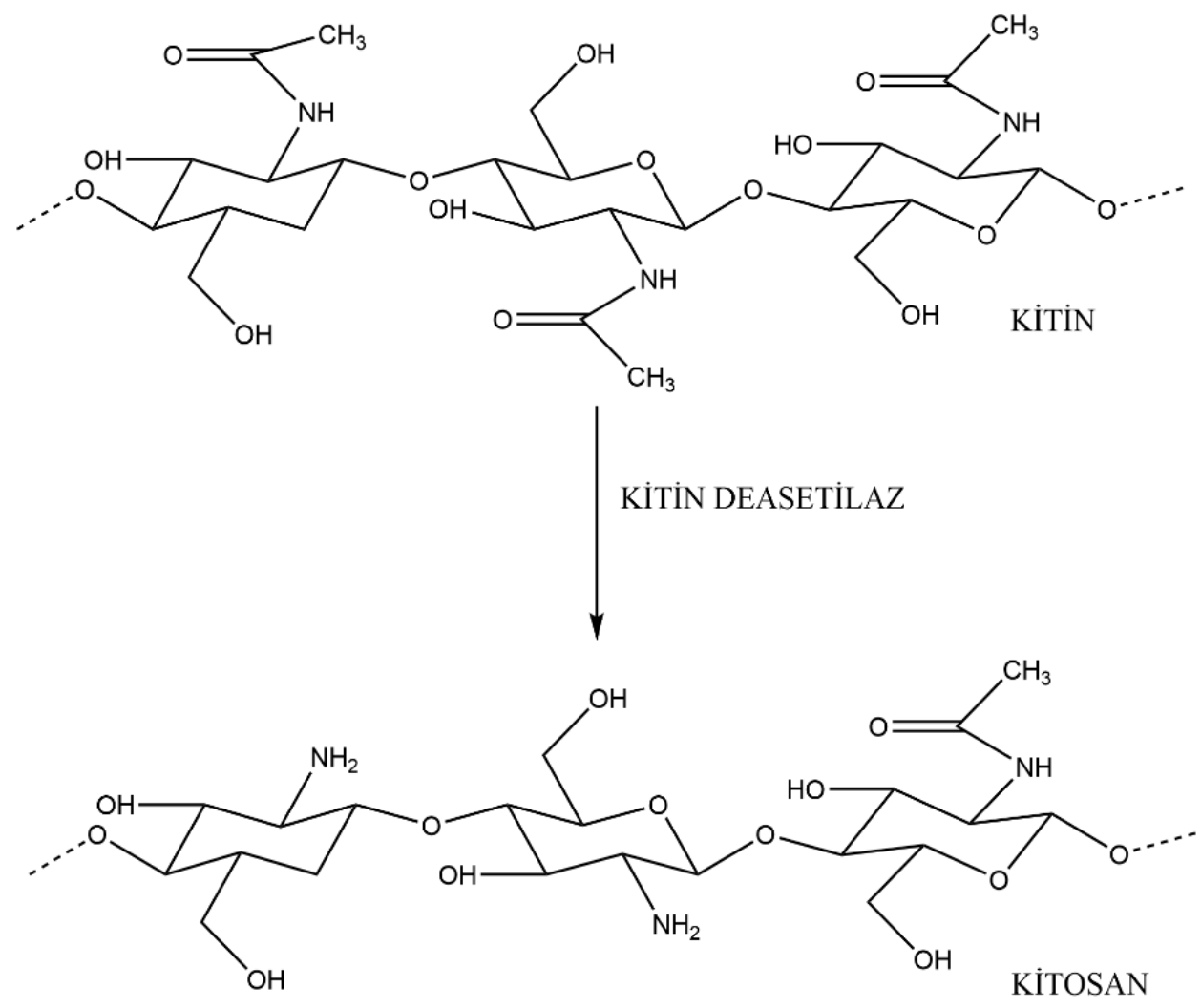

Kitin ve kitosanın yapışkan yapısı antifungal ve bakterisidal özelliği ve oksijen geçirgenliği nedeniyle yara tedavisinde kullanılmaktadır. Kitin ve kitosanın benzer amaçlarla hidrojel, fiber, membran, scaffold ve sünger formları hazırlanmaktadır. Fibril yapıdaki kitin ve türevlerini; yüksek mukavemeti, biyouyumluluğu, düşük toksisitesi, sıvı absorpsiyonu ve antibakteriyel aktivitesi gibi özellikleri vardır. Bu özellikler de yara iyileştirme hızını arttırır. Kitosan-kollajen membranlar da yara iyileştirmesini hızlandırmak hücre göçü ve proliferasyonunu arttırmak amacıyla kullanılır. Polipropilen-NIPAAm-kollajen-kitosan membran ısıya duyarlı malzeme olarak yara 
iyileştirmesini ivmelendirmektedir. Kitin-kitosan tabanlı hidrojeller yara iyileştirmesini ve hızlandırma kabiliyeti nedeniyle yara tedavisi için kapatıcı örtü olarak düşünülebilir. Ayrıca hidrojellerin nem geçirgenliği özelliği bol eksudalı yaralarda sıvı artışı olmasını engeller. İyileştirme aktivitesini arttırmak için kitin-kitosan tabanlı membranlar aljinat, hiyaluronik asit, polietilen glikol diakrilat, polivinil-alkol, $\mathrm{\gamma}$-poli (glutomik asit) ve 2hidroksietil metakrilat gibi farklı tipte polimerlerle geliştirilebilmektedir. $\mathrm{Ag} / \mathrm{ZnO}$ bağlantılı kitosan membranlar, geleneksel malzemelerden daha az sitotoksiktir. Antibakteriyel aktivitesinin geliştirilmesine bağlı olarak hücre yapışma kabiliyeti ve oksijen geçirgenliğinden kitin-kitosan scaffold/köpük yara örtüleri gelecek vaad etmektedir ${ }^{21}$. Gümüş sülfadiyazin ile birleştirilmiş tek katlı kitosan yara örtülerinin mükemmel oksijen geçirgenliği, su buharı geçirme oranı ve su tutma kapasitesi olduğu gösterilmiştir ve 1 haftalık in-vitro kültürde mükemmel antibakteriyel aktivite sergilediği gözlemlenmiştir ${ }^{22}$. Kitosan yara örtü malzemesi olarak bu denli geniş çapta çalışılmasına rağmen henüz birkaç kitosan tabanlı yara örtüsü geniş çapta ticarileştirilebilmiştir²3. Kitin-kitosan köpük formu yumuşak ve esnek, mikro gözenekli olduğundan sıvı absorpsiyon kapasitesi yüksek hücre etkileşimi ve hidrofiliklik düzeyi de yüksek seviyedir. Ancak mekanik olarak oldukça zayıftır. Düşük malzemeler ile yapı mekaniği/dayanımı da arttırılabilir. Yara yüzeyi yeteri kadar nemli tutulmalıdır ancak enfeksiyon riski nedeni ile yara ve örtü arasında sıvı birikimi de olmamalıdır. Bakteriyel invazyon; bakteri popülasyonun büyümesi nedeniyle deri graftlama yara için uygun olmayabilir. Bu yüzden yara örtüsü sünger benzeri (yüksek gaz geçirgenliği ve enfeksiyon dehidratasyonundan yarayı koruma özelliği olan ara tabaka) bir üst tabaka ile desteklenmelidir²4. Köpük örtüler kullanılarak; nem tutma kapasitesi, yüksek şişme kabiliyeti ve skar yapısı oluşumu dışındaki yara iyileştirmesi sağlanabilmektedir. Son yıllarda gözenekli köpük tipi örtüler $\beta$-kitin tabanlı hazırlanmaktadır²1. Bu ürünlerde oksijen geçirgenliği de yeterli bulunmuştur. Bu sünger tipi örnekler yara yüzeyinde bakteri enfeksiyonunu önlemek için antimikrobiyel ajanları ve gümüş sulfadiyazini içermektedir. $\mathrm{Bu}$ materyallere gümüş sülfadiyazin emdirilmiştir ve 7 günden fazla P.aeruginosa’ya karşı bakterisidal özellik göstermiştir.

2004 yılında antibiyotik ilaç, norflokosin ile enkapsüle edilmiş kitosan süngerleri yara örtü malzemesi olarak şekillendirilmiştir²5. Çapraz bağlı kitosan süngerler evaporasyon tekniği ile hazırlanmıştır. Sonuçta elde edilen sünger, fibril yapıdadır. Bu çalışmada 
kitosan süngerlerin; emme davranışı, norflokosin yüklemesi, in-vitro özelliği ve antibakteriyel aktivitesi olduğu sonucuna ulaşılmıştır. En etkileyici parametre olarak da nötralizasyon derecesi görülmüş̧ür. Norfloksasin salınımının, ilk olarak şişme kontrolü sağladığı bulunmuştur ve diğer genişleyen salınım periyotlarında difüzyon kontrolü yaptığı teşhis edilmiştir. Antibakteriyel aktivite ile salınım oranı doğrudan ilişkili (orantılı) olduğu sonucuna ulaşılmıştır. Yarısı kitosan yarısı standart malzeme ile üretilmiş bir yara örtüsü kesik yarasında denemiş ve kitosanın olduğu bölgede daha hızlı re-epitelizasyon ve damarlanma oluştuğu gözlemlenmiştir ${ }^{26}$. 2010 yılında ise kitosan hidrojeli ile birleştirilmiş $\mathrm{ZnO}$ sentezlenmiştir²7. Gözenekli kitosan-ZnO kompozit sünger, freeze drying yöntemi ile hazırlanmıştır. Nanokompozit süngerin antibakteriyel, şişme, kan pıhtılaşması, sitotoksiste ve hücre bağlama özellikleri değerlendirilmiştir ve bu özellikleri sağladığı sonucuna varılmıştır. Sitotoksiste çalışmaları, bu malzemenin insan-deri fibroblastlarına ve doğru hücre bağlarına karşı toksik olmadığını göstermiştir. Dolayısıyla bu sonuçlar ZnO-Kitosan nanokompozit süngerin yara örtü malzemesi olarak kullanım uygunluğu da kanıtlanmıştır ${ }^{21}$. Çünkü, hücrelerin gelişmesi için destek sağlar, enfeksiyon oluşumuna karşı bariyer görevi görür, iyileşme için protein sağlar, yeni dokuyu güçlendirir, inflamasyondaki sıvıyı absorblar, acıyı azaltmak için sinir hücreleri ile bağlantıyı engeller, kan hücrelerinin göçünü hızlandırır ve skar dokusunu minimize edebilmektedir. Çeşitli hayvanlar üzerinde yapılan çalışmalar sonucunda kitosan ile yapılan yara tedavisinde minimum skar dokusu oluşumu baz alınarak tedavi süresinin kısaltıldığ 1 ispatlanmıştır ${ }^{28}$. Diğer bir çalışmada ise kitosanın laktik asit (Kitosan-LA) ve asetik asit (Kitosan-AA) ile birlikte kullanımı test edilmiştir ${ }^{29}$. Bu araştırma sonucunda

Kitosan-LA çekme dayanımı daha düşük fakat daha esnek ve Kitosan-AA'ya göre daha yapışıcıdır; Kitosan-LA deriye herhangi bir alerjik reaksiyon göstermezken Kitosan-AA göstermiştir; ancak ikisinin de toksik olmadığı görülmüşsür. Bu çalışmanın sonucunda ise Kitosan-LA yara iyileştirmede daha uygun bulunmuştur.

\section{Kollajen}

Bağ dokuda bolca bulunan biyobozunur ve biyouyumlu bir proteindir ${ }^{11}$. Şekil 2'de kollajenin yapısı gösterilmektedir. Kollajenin yapısı ilk olarak Astbury tarafından 1938 yılında ortaya konmuştur3o. Şekil 2'den de görüldügü üzere kolajen birbiri üzerine sarılmış 3 zincirden meydana gelmektedir ve her bir zincir 1400 amino asit uzunluğundadır. 3 aminoasidin tekrarlanmasından meydana gelir. İçeride kalan 3 . 
amino asit glisindir. Dışarıda ise prolin ve hidroksiprolin bulunur. İlk medikal kullanımı 1970'li yıllarda doku çevre kenar bozukluklarının co-reaksiyonunu sağlamak için gerçekleştirilmiştir ${ }^{31}$. Daha sonraki yılarda sığır kollajeni yara kenarlarının birleştirilmesinde ve hemostatik ajan olarak kullanılmıştır. 1980’de sığır kollajenin sterilize fibrilleri yara yüzeyinin altına enjekte edilerek kullanılmıştır. Günümüzde ise kollajen çok sayıda biyomedikal uygulamada kullanılmaktadır ${ }^{2}$. Dermal enfeksiyon için: topikal hemostatik ajanlar; periodantal yapılanması için: yara örtü malzemeleri, kollajen süturlar, catgut (dikiş ipliği), kollajen jeller; Hemostas için: kollajen köpükler ve diğer kollajen yara örtü malzemeleri bu kapsamdadır.

Şekil 2. Kollajenin yapısı<smiles>CCC(C)C(NC(=O)CNC(=O)C1CCCN1C(=O)C(CCC(=O)O)NC(=O)CN)C(=O)NC(C)C(=O)NCC(=O)NC(Cc1ccccc1)C(=O)NC(CCCCN)C(=O)NCC(=O)NC(CCC(=O)O)C(=O)NC(CCC(N)=O)C(=O)NCC(=O)N1CCCC1C(=O)NC(CCCCN)C(=O)O</smiles>

\section{Aljinik Asit/Aljinat}

Aljinik asit, Laminaria ve ascophyllum türevleri gibi kahverengi alglerden doğal bir polisakkarit türevidir. D-mannuronik asit ve L-guluronik asitin lineer blok kopolimerizasyonu ile şekillendirilir ${ }^{11}$. Yapısal olarak modifiye edilmiş aljinatlar doku mühendisliği alanında yara iyileşmesi ve kontrollü ilaç salınımı amacıyla çeşitli potansiyel uygulamalar için uygun bulunmaktadır33. Hemostazik özelliklerinden dolayı da yara ve yanık tedavisinde kullanılırlar. İlk kullanımı jel şeklinde olmuştur. Fakat kalsiyum aljinattan üretilen köpük formu yara tedavisinde daha etkindir. Ayrıca kalsiyum aljinatın, hücresel aktivite özelliklerini (adezyon ve proliferasyon gibi) de arttırdığı belirtilmektedir34. 
Şekil 3. Aljinik asit yapısı

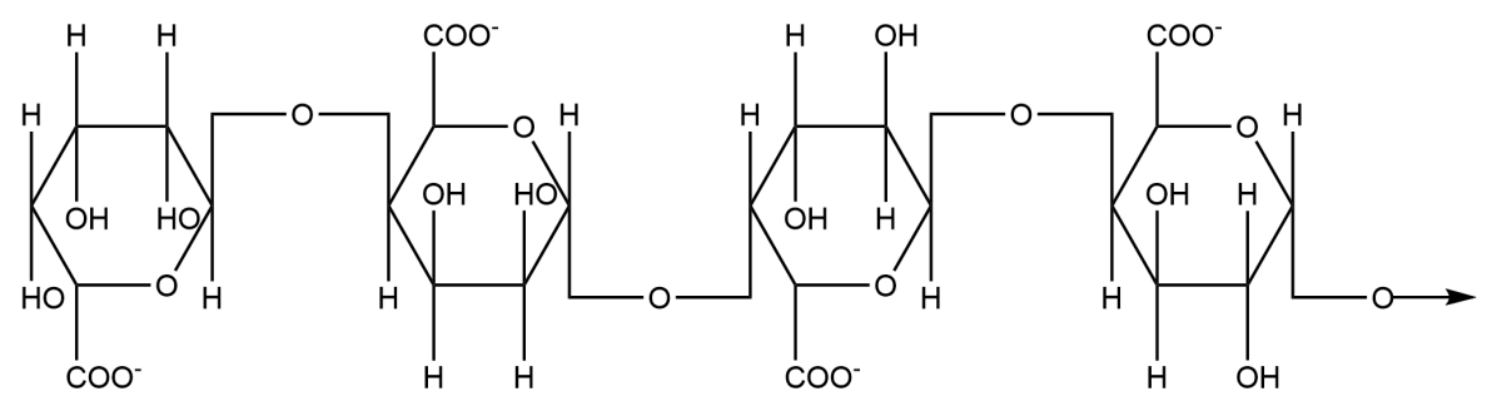

ALJiNIK ASIT

Aljinat liflerinin büyük oranda iyon değişim özelliği vardır ve yara ile temas halindeyken lifteki kalsiyum iyonları vücut sıvısındaki sodyum iyonlarıyla yer değiştirir. Böylece lifin bir bölümü sodyum aljinat haline gelir. Sodyum aljinat suda çözünebilme özelliğine sahiptir. Bu iyon değişimi, lifin şişmesine neden olur ki bu durum da ve jel haline gelmesine neden olur. Bu nedenle aljinat lifleri nemli iyileştirici olarak bilinirler ve yara örtü üretiminde sıklıkla kullanılırlar. Farklı deniz yosunlarından elde edilen çeşitli fonksiyonlara sahip aljinat çeşitleri mevcuttur. Ayrıca; çinko kanamayı dindirici özelliğinden dolayı aljinat ile kombine edilerek de kullanılmaktadır ${ }^{12,35}$. Ayrıca aljinat liflerini daha çok emici kılmak adına sodyum iyonları, kalsiyum aljinat liflerine eklenebilmektedir3o ${ }^{30}$ Alginat örtüler yapışkan değildir ve kullanımı kolaydır ve hidrofilik özellikte olduklarından, ağırlıklarının 20-30 katı kadar eksudayı absorblayabilmektedir. Eksuda ile temas halinde iken kalsiyum ve sodyum iyon değişimi ile meydana gelen hidrofilik aljinat jeli, yara iyileşmesi için nemli yara ortamı sağlamakta ve bu nedenle de epitelizasyon ve granülasyon doku oluşumunu artmaktadır. Diğer yandan aljinat içerikli örtü tarafından serbest bırakılan kalsiyum iyonları, pıhtılaşmayı sağlayan protrombin maddesinin aktivasyonuna yardımcı olurken, kalsiyum ve lifli matrisin varlığı ise kanın pıhtılaşmasında etkili olan materyalleri desteklemektedir ${ }^{30}$. Geleneksel gazlı bez yara örtüsü ile karşılaştırıldığında esnek, ince, saydam, kitosan-aljinat polielektrolit kompleks (PEC) membranlar, kesik yaralarında iyileşmeyi hızlandırdığı sıçanlarda denemiş ve pozitif sonuç alınmıştır ${ }^{6}$. Bazı aljinatlar, mast hücrelerinin, (makrofajların, bağışıklık sisteminde etkili hücrelerin) aktive olmasını sağlamakta37,38 ve böylece histamin ve 5 HT'nin salınımına neden olarak yara iyileşme mekanizmasını başlatabilmektedir. Bu nedenle, kalsiyum aljinat örtülerin biyoaktif materyal olarak da 
kullanımları mümkündür. Ayrıca antibakteriyel özelliğe sahip olmayan aljinat, bakterileri pasif olarak jel içerisinde hapsederek örtü değişimi ile bu bakteri uzaklaştırabilmektedir ${ }^{13}$.

\section{Hyaluronik Asit ve Türevleri}

Hyaluronik asit (HA), glukuronik asit ve $\mathrm{N}$-asetilglikosaminin disakkarit birimlerinin bağlanmasıyla oluşan bir mukopolisakkarittir39. D-glikuronik asit ve 2-asetilamido-2deoksi-D-glikoz için bir alternatif olarak düşünülen doğal polimerlerden biridir ve genellikle memeli bağ dokusu ve sinoviyal sıvıda bulunmaktadır40. Hyaluronik asitin; preoteoglikan, büyüme faktörleri ve doku bileşenleri olarak adlandırılan yara iyileşmesinde görevli biyomoleküller ile etkileşime girdiği rapor edilmiştir ${ }^{41}$. Sözkonusu bu etkileşim de doku onarımında ve yara iyileşme hızında artışa neden olmaktadır. Ayrıca Hyaluronik asit, mikroorganizmaların bakteriyostatik etkisine karşı yaralı bölgenin korunmasında da rol oynamaktadır ${ }^{11,42}$. Şekil 4'de hyaluronik asitin yapısı gösterilmiştir.

Şekil 4. Hyaluronik asit yapısı

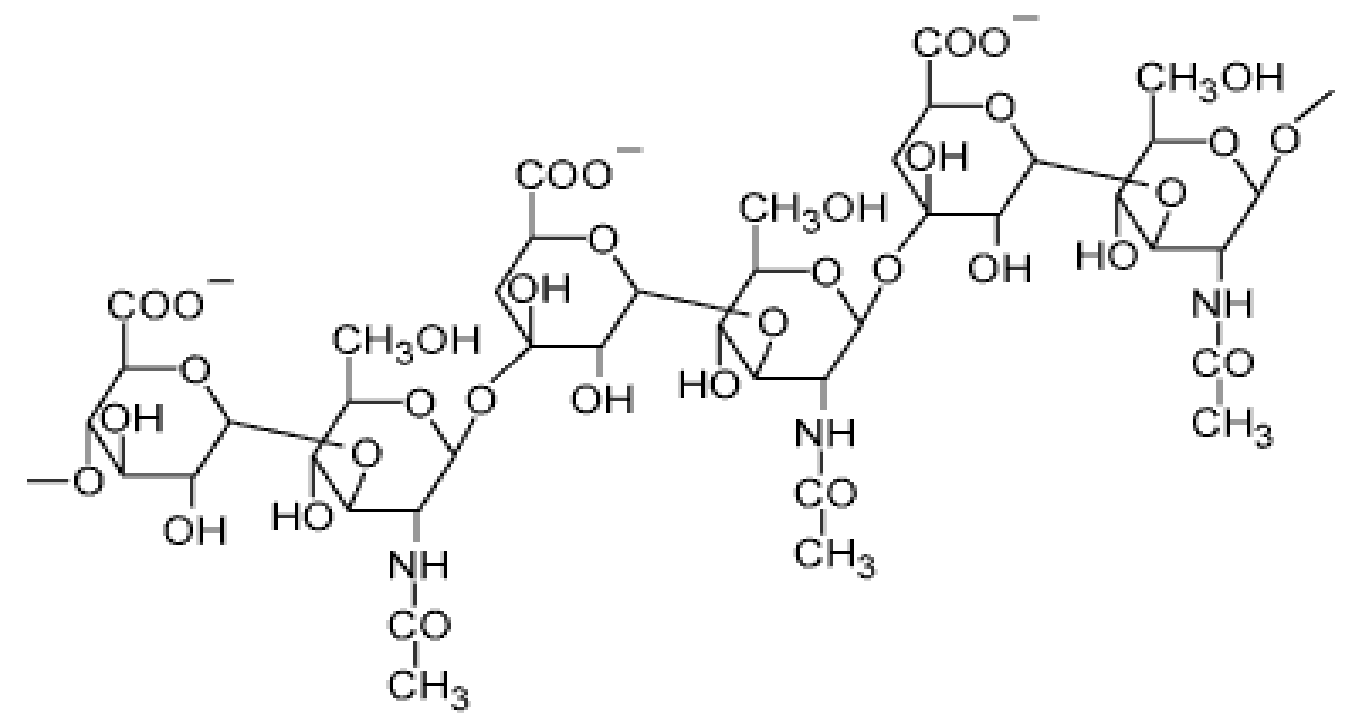

2007'de yapılan bir çalışmada kitosan ve hyaluronik asit kompozitinin yara iyileştirme üzerinde etkisi incelenmiş43 ve bu çalışmada yara örtüsü içeriğindeki hyaluronik asit miktarı arttırıldıkça yara örtüsü yüzeyindeki pürüzlülüğünün arttı̆̆ı Atomic force 
microscophy (AFM) ile gösterilmiştir. Bu durum yara örtüsünün yara yüzeyine daha iyi tutunmasını sağlamaktadır. Ancak Hyaluronik asit miktarının artışı aynı zamanda yara iyileşmesinde etkin parametreler olan su buharı geçirgenliğini, fibroblast yapışmasını ve protein adsorpsiyonunu azalttığı tespit edilmiştir. Bu nedenle kompozit üründeki hyaluronik asit miktarının doğru ayarlanması gerekmektedir. In vivo hayvan testlerinde vazelin gazlı bez ile kitosan-hyaluronik asit kompozit yara örtüsü karşılaştırıldığında kompozit malzemenin yarayı daha etkin ve hızlı iyileştirdiği ve örtü tekrar uygulandığında da yarada yeni bir hasar oluşmadığı ortaya çıkmıştır. Bu çalışma ile kitosan-hyaluronik asit karışımının yara örtülerinde kullanımı etkin ve ekonomik bulunmuştur.

\section{Fukoidan}

Fukoidan bir sülfat polifukoz polisakkarittir ve kahverengi deniz yosunundan elde edilir44. Koagülant aktivitesininheparin ile benzer oluşu ve antitrombotik, antiinflamatuar, antitümoral, antiviral etkisini kapsayan özelliklerinden dolayı biyoteknolojik araştırmalarda kullanımı cezbedici olmaktadır ${ }^{44,45}$. Bu etkilerin birçoğu temel bazik fibroblast büyüme faktörü (bFGF) ve dönüştürücü büyüme faktörü (TGF- $\beta$ ) gibi büyüme faktörleri ile iletişiminden dolayı olduğu düşünülmektedir. Bu nedenle fukoidan, doku onarımında hücre biyolojisi içindeki büyüme faktörleri ile bağımlı iyileşme yollarından şekillendirilebilir ${ }^{46}$. Son yıllarda ilaç ve gen taşıma sistemleri, teşhis edici mikropartiküller ile fukoidanın yara iyileştirme fonksiyonu da geliştirilmektedir 44,47 .

Şekil 5. Fukoidan yapısı

\section{Fuc $\alpha 1$}

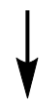

$\longrightarrow$ 3Fuc $\alpha 1-3$ Fuc $\alpha 1-3$ Fuc $\alpha 1-3$ Fuc $\alpha 1-3 F u c \alpha 1 \longrightarrow$

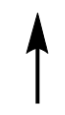

Fuc $\alpha 1$

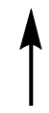

$\mathrm{SO}_{3}{ }^{-}$

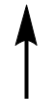

$\mathrm{SO}_{3}^{-}$

FUKOIDAN 
Fukoidanın birçok çeşidi mevcuttur. Örneğin ilk kez 1913'de kahverengi algden ( $F$. vesiculosus) izole edilen fukoidan, fukoz ve sülfat gibi basit yapılı bileşenleri içermektedir. Fakat her bir fukoidanın kimyasal bileşimi birbirinden farklıdır ve çoğu çeşidi daha karmaşıktır. Bu yapılar fukoz ve sülfat dışında diğer monosakkaritleri (mannoz, galaktoz, glukoz, ksiloz vb.), üronik asiti, asetil gruplarl, proteinleri ve benzeri bileşenleri de içermektedirler. Hatta kahverengi alg türünden türüne göre fukoidan yapısı değişim göstermektedir. Bu da her bir fukoidan yapısının farklı fonksiyon gösterebileceği ihtimalini doğurmaktadır. Kahverengi alg’in 9 farklı türü ile yapılan bir çalışmada fukoidanın antikoagülant aktivitesi test edilmiştir. Cladosiphon Okamuranus dışındaki tüm fukoidanlar, 2-O- $\alpha$-D-glikuronopiranosil lineer dalları $(1 \rightarrow 3)$-poli- $\alpha$ fukopiranosit zinciri ile bağlıdır. L.saccharina, L.digitata, F.serratus, F.distichus ve F.evanescens tiplerinde platelet birikimi testinde güçlü antitrombin aktivitesi olduğu sonucuna varılmıştır. Birçok çalışma fukoidanın antikoagülant aktivitesinin yapısındaki sülfat içeriği ve pozisyonu, molekülar ağırlığı, glikoz bileşimi ile ilişki olduğunu göstermiştir. Yüksek oranda sülfat grubu içeren fukoidanlar daha yüksek oranda antikoagülant aktivitesi göstermişlerdir. (Ör. E.kurome, H.fusiforme). Ancak sülfat oranının da optimum düzeyde ayarlanması gerekmektedir. Aksi takdirde gereğinden fazla sülfat grubun eklemesi antikoagülant aktiviteyi ve antitrombin etkisini aynı oranda düşürmektedir 48,49 .

\section{Poli-N-Asetil Glikozamin}

Su mikroalglerinden üretilen bu malzeme hemostatik etkiye sahiptir ${ }^{47}$. Bu nedenle yara tedavilerinde destek malzeme olarak kullanılmaktadır ${ }^{50}$. Şekil 6'da Poli-N-Asetil Glikozamin yapısı gösterilmiştir. 
Şekil 6. Poli-N-asetil-D-glikozamin yapısı

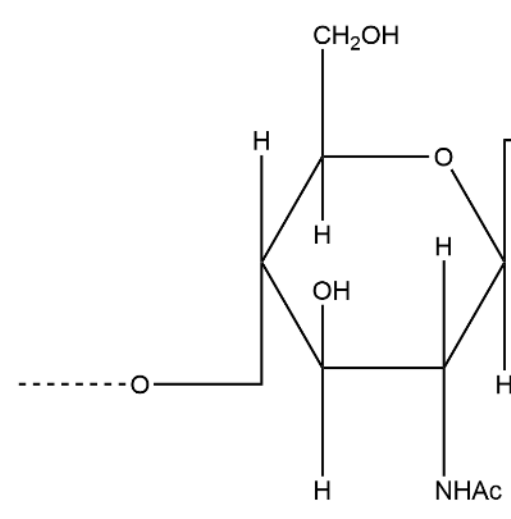

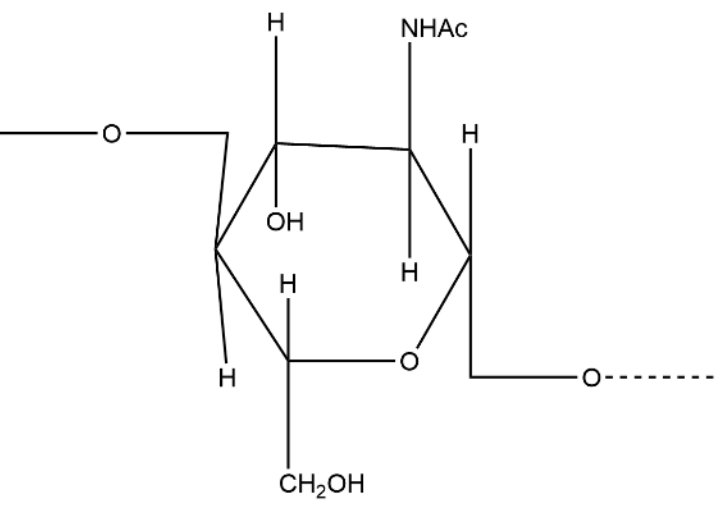

Poly-N-acetyl-D-glucosamine

\section{Sentetik Polimerler}

Yara örtülerinde en sık kullanılan ve yara iyileşmesine katkısı olduğu düşünülen sentetik polimerler poliüretan ve türevleri, teflon, proplast, metil metakrilat, silikon olarak siralanmaktadır 51 .

\section{Poliüretan ve Türevleri}

Poliüretanlar, genellikle diol gruplar ve dizosiyanat grupların polimerizasyon reaksiyon konjugasyonlarıyla şekillendirilirler. Büyük miktarda toksik olmayan poliüretan biyomedikal uygulamalarda kullanılmak üzere sentezlenmektedir. Bunlardan biri de Pellethane 2363-8oA'dır ve bu malzeme yara tedavisinde yara örtü malzemesi olarak kullanılmakta ve yeniden epitalizasyonu hızlandırıcı olarak işlev görmektedir ${ }^{2}$. Şekil 7’de poliüretan yapısı gösterilmiştir.

Şekil 7. Poliüretan yapısı

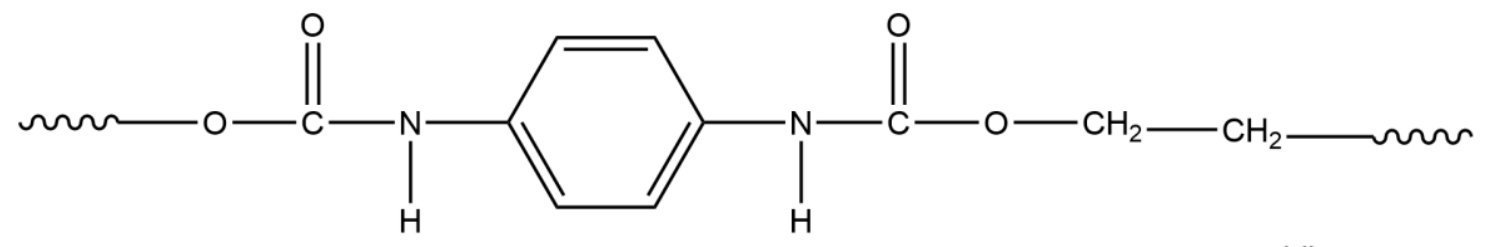

POLIÜRETAN 
Poliüretan filmler, yara-bakım materyallerinde yarı-geçirgen saydam filmler havayla taşınan bakterilerin yaraya bulaşmasını önlerler. Diğer yandan da gaz geçişine izin vermektedirler. Filmlerin yarı-geçirgen yapısı nedeniyle yüksek oranda nem buharı yara yüzeyine iletilmiş olur. Ancak bu durum eksuda absorpsiyonunun da engellenmesine neden olur. Çünkü su ve mikroorganizmaların geçişi engellenmektedir. Eksuda absorpsiyonu sağlayamadığından poliüretan filmler kuru yaraların tedavisinde tercih edilmektedir53,54. Genellikle film formundaki yara örtülerinde polimer ve film yapısı birleştirilerek, film boyunca iletilen nem buharı oranı ayarlanabilmektedir. Film formundaki poliüretan yara örtüleri hafif esnektir, yara yüzeyine iyi şekilde yapışmaktadır, biyo uyumludur, sürtünmeye karşı deri hasarını önlemek için de idealdir ${ }^{12,30,55 .}$

Poliüretan köpükler, hem esnek hem de yüksek absorbsiyon kapasitesine sahip gözenekli, yumuşak, nispeten yüksek dayanım ve aşınma direncine sahiptir56. Poliüretan, hidrofobik veya hidrofilik monomerlerden elde edilebilmekte ve sonuçta farklı gözeneklilik ve sıvı tutma kapasitesine sahip köpükler üretilmektedir. Eksudalı yaralarda, yara sıvısı köpük içerisine absorbe edilmektedir. Kuru yaralarda ise, poliüretan buhar kaybını azalmakta ve yara yüzeyinin kurumasını önlemektedir57.

\section{Teflon}

Tetrafloroetilen'in yüksek ısı ve basınç altında polimerizasyonu ile sentezlenmektedir36. Karsiyojenik olmayan, polar ve nonpolar çözücü içinde çözünmeyen, sterilize edilebilir inert bir malzemedir. Düşük basınç ile şekillendirilip kolayca yara bölgesine uygulanabilir. Şekil 8'de teflon yapısı verilmiştir.

Şekil 8. PTFE (Poli(tetrafloroetilen))-Teflon yapısı

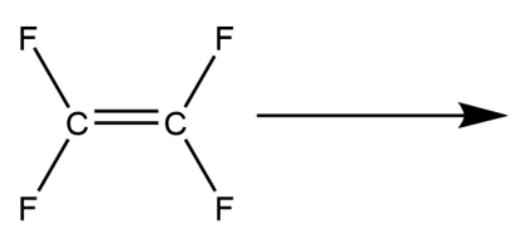

TETRAFLOROETILEN

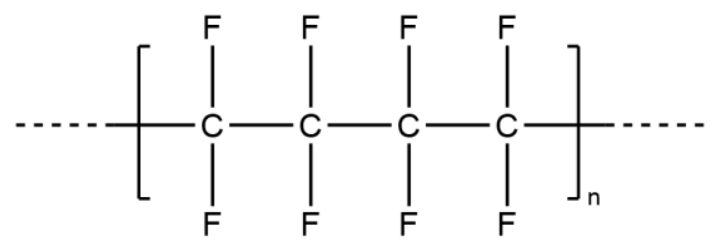

POLİ(TETRAFLOROETILLEN)

\section{Proplast}

Proplast, sert propilen tabakadır. Şekillendirme için oldukça dayanıklı bir malzemedir58. 
Temas ettiği yüzeyi kontamine etmez, yeniden dönüştürülebilir, $120{ }^{\circ} \mathrm{C}$ üstünde sterilize edilebilir, darbelere karşı yüksek dayanımlı, maliyeti düşük, depo edilebilir ve uzun raf ömrüne sahiptir. İlk sentetik biyomalzeme, proplast olarak bilinen poliproplendir. Özellikle implant uygulaması için geliştirilmiştir ${ }^{6}$. Yara, yanık, ameliyat uygulamalarında, yüksek biyouyumluluğundan dolayı tercih edilmektedir59. Şekil 9'da proplast yapısı gösterilmiştir.

Şekil 9. Polipropilen (proplast) yapısı

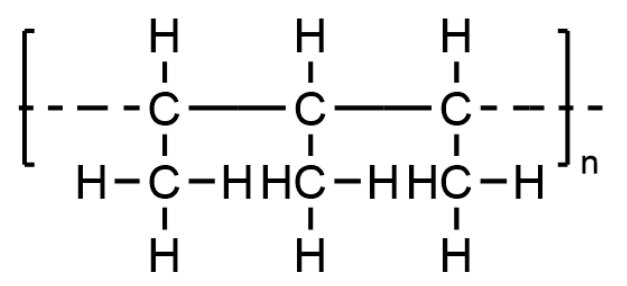

\section{POLİPROPILEN}

\section{Metil Metakrilat}

Biyobozunur olmayan sentetik bir polimer olup ısıya ve UV ışınına dirençlidir36,60. Estetik cerrahi ve yara tedavisinde destek malzeme ve yara örtüsü olarak kullanılmaktadır61. Şekil 10’da polimetil metakrilat yapısı gösterilmektedir.

Şekil 1o. Polimetilmetakrilat (PMMA) yapısı<smiles>C=C(C)C(=O)OC</smiles>

METİLMETAKRIILAT

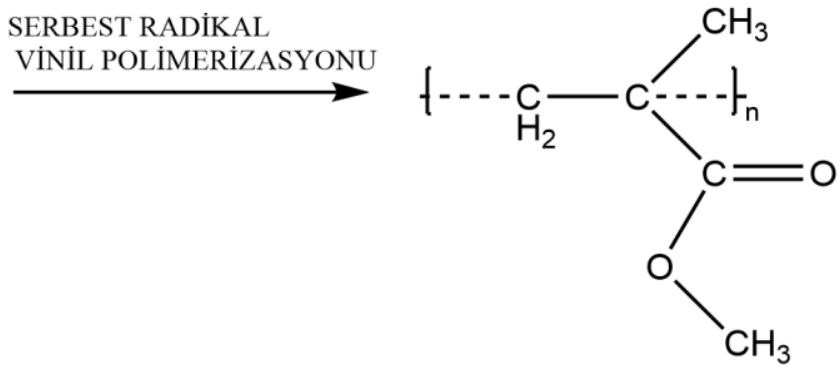

POLİ(METİLMETAKRİLAT)

\section{Silikon}

Silikon, Dünya üzerinde en bol bulunan ikinci elementtir62. Büyük çapta biyomedikal uygulamalarda kullanılmaktadır. Düşük toksisite, düşük alerjik özellik ve vücutta yüksek 
biyouyumluluğa sahiptir36,63. Biyobozunmaya dirençlidir. Yumuşak doku onarımında kullanılan elastomerler, implantların hazırlanmasında ve hipodermik iğne ve şırınga üretiminde kullanılmaktadır64 ${ }^{6}$ Ayrıca silikon, birçok yara ve yanık tedavisinde yüksek doku uyumundan dolayı destek materyal olarak sıkılıkla kullanılmaktadır ${ }^{36}$. Şekil 11'de silikon yapısı gösterilmiştir.

Şekil 11. Silikon yapısı - (poli(dimetil)siloksan)<smiles>CCC(C)(O[Si](C)(C)C(C)(C)C)[Si](C)(C)C</smiles>

Silikon köpük yara örtüleri vizkoz polidimetilsiloksan ve kalaylı oktanat katalizöründen elde edilmektedir. Bu iki madde karıştırılarak yara içine dökülmektedir. Bu karışım oda sıcaklığında sertleşir ve özellikle derin yaralarda yara içine döküldüğü formda kalabilmektedir57. Herhangi bir biyoljik bileşen içermeyen slikon kaplı nylon yara örtüsü ile standart gümüş sülfadiyazinli krem, 66 çocuğun yanık tedavisinde test edilmiştir65. Gümüş sülfadiyazinli krem pediatrik yanık tedavilerinde genel kabul görmüş bir tedavi ürünüdür. Yaranın derinliği, örtünün epitel tabakayı örtme oranı, enfeksiyon kanama ve alerjik değerleri her bir yara örtüsü için not edilmiştir. Silikonlu yara örtüsü 41 çocukta, sülfadiyazinli krem 35 çocukta uygulanmıştır. İki gruptan da 5 çocuk için ise deri graftlama gerekmiştir. Yapılan analiz sonucunda her iki grupta da yara iyileşme süresi dışında bir iyileşme kriteri farklılı̆̆ı gözlemlenmemiştir. Silikonlu örtü, yaradan daha kolay ayrılabilmiştir. Ayrıca silikonlu örtünün daha hızlı iyileştirdiği sonucuna ulaşılmıştır. Bunun nedeni epitel dokunun gelişmesine silikonun etkisi ya da yaranın örtü değişiminde hasar görmemesi olabileceği belirtilmiştir.

\section{Polimerik Yara Örtüsü Tasarımı}

Diyabetik bası ülseri gibi kronik yaralar için Uner-Bahar ve Işıldak tarafından poliüretan köpük formda çok katmanlı larva yüklü bir yara örtüsü geliştirilmiştir ${ }^{66}$. Maggot tedavi yönteminde steril $L$. sericata cinsi sinek larvaları bası, bacak ve ayak ülserinde yara debridmanı sağlamak amacıyla kullanılmaktadır ${ }^{67}$. Bu çalışmada larva yüklü yara 
örtüsünde, sterilize edilmiş Lucilia Sericata cinsi sinek larvaları uygun büyüklükte oluşturulan yuvalara yerleştirilip üstü gazlı bez benzeri bir yapı ile kapatılarak hapsedilmesi planlanmıştır. Böylelikle larva yayılmasının sadece yara bölgesinde sınırlı kalması hedeflenmişdir. Tasarlanan polimerik yara örtü malzemesinin fiziksel uygunluğu yanında kimyasal uygunluğunun sağlanması da oldukça önemlidir68. Yara iyileşmesinde esas olan, yara bölgesinin nemli tutulmasının ve oksijen geçirgenliğinin sağlanmasıdır. Ayrıca larvaların etkinliği de kaybedilmemeli ve larva salgılarının yara bölgesine ulaşması engellenmemelidir. Diğer yandan yara örtüsü yara bölgesine kolay uygulanmalı ve istenildiğinde yaraya zarar vermeden kolayca çıkarılabilmelidir. Yapılan tasarımda biyouyumlu poliüretan köpük formda bir polimerik malzeme kullanılmıştır. Hasta hareket ederken ya da duşa girdiğinde de yara örtüsü yerinden oynamayacak şekilde sağlam yapışmış ve su geçirmez nitelikte olması planlanmıştır. Geliştirilen yara örtüsüne larvaların yüklenmesi ile yara debridmanı, larva salgıları ile sağlanırken biyouyumlu yara örtüsü larvalara oksijen geçişini sağlayarak larvaların ölmesini engellemektedir. Ayrıca larvaların sınırlı bir bölgeye hapsedilmesi ile hasta hareket halindeyken maggotların dışarı kaçmasına ve yara bölgesinde oluşabilecek enfeksiyonun oluşmasına engel olunmaya çalışılmıştır. Böylece hastanın klinik dışında tedavisinin sağlanması öngörülmüştür. Diğer yandan yara örtüsünün su geçirmeyen bir malzeme ile kaplanması hastanın uzun süren tedavi süreçlerinde duşa girebilmesini sağlayacaktır. Ayrıca yara örtüsüne ısıl stabilizatör eklenerek yaradaki granülasyon doku oluşumunun hızlandırılacağı öngörülmüştür. Bu öneriler henüz tasarım ve ön-uygulama aşamasında olup, başarılı sonuçlar alınması durumunda birçok iyileşmeyen yaraya sahip hastalara daha yüksek iyileşme şartlarında, daha hızlı bir yara iyileşme olanağı sağlanmış olacaktır.

\section{Sonuç}

$\mathrm{Bu}$ makalede yara iyileşmesinde bakım ürünü seçimi ve polimerlerin yara iyileşmesi üzerine etkileri incelenmiş olup yara iyileştirme özellikli doğal ve sentetik polimerler özetlenmiştir. Son yıllarda geliştirilen polimerik yara örtüleri sayesinde kronik yara tedavilerinde de büyük bir aşama kaydedilmiştir. Günümüzde kitin/kitosan, kollajen ve aljinat iyileştirme özellikleri ve biyouyumlu olmaları nedeniyle yara iyileştirme materyali olarak öne çıkmaktadır.

Ülkemizin son yıllarda yaptığı sağlık harcamaları dikkate alındığında; hastanede tedavi gören hastaların dikkate değer bir bölümü çeşitli yara tedavileri nedeniyle hastanede 
kalmakta ve bu hastalara sürekli pansuman yapılmaktadır. Bu durum ülkemize ve bireylere ciddi bir maliyet yüklemektedir. Özellikle iyileşmeyen yaraların pansumanı için kullanılan sarf malzemelerin büyük çoğunluğunun da ithal olduğu düşünülürse tedavi maliyetlerin çok daha büyüyebileceği dikkate alınmalıdır. Bu nedenle etkili yara örtü ve ürünlerinin geliştirilmesi hasta yaşam konforunun yükseltilmesi ve yara bakım maliyetlerinin düşürülmesi arttırması açısından büyük önem taşımaktadır.

\section{KAYNAKLAR}

1. Kumar B, Vijayakumar M, Govindarajan R, Pushpangadan P.

Ethnopharmacological Approaches to wound healing: exploring medicinal plants of India. Journal of Ethnopharmacology. 2007;114:103-113.

2. Altındaş M. Kronik yara tedavisi ve bakımında tıbbi sorunlar. İ.Ü.Cerrahpaşa Tip Fakültesi Sürekli Tıp Ĕ̆itim Etkinlikleri. Yara Bakımı ve Tedavisi Sempozyum Dizisi. 2008;67:237-247.

3. Lanza R, Langer R, Vacanti J. Principles of Tissiue Engneering. Third Edition. Academic Press; 2007.

4. Özkorkmaz G, Özay Y. Yara iyileşmesi ve yara iyileşmesinde kullanılan bazı bitkiler. Ahi Evran Üniversitesi Sağlık Yüksekokulu Kırşehir Türk Bilimsel Derlemeler Dergisi. 2009;2(2):63-67.

5. Çakal C. Polihema Bazlı Yara/Yanık Örtü Materyalleri. [Yüksek Lisans Tezi]. Ankara, Türkiye: Hacettepe Üniversitesi Fen Bilimleri Enstitüsü Biyomühendislik Anabilim Dalı;2004.

6. Erdoğan B. Kronik Yara ve Modern Yara Bakımı Ürünleri. In: 2.Özel Yara Bakım Kongresi; 2007; Ankara Üniversitesi Plastik Ve Rekonstrüktif Cerrahi A.D, Ankara, Türkiye.

7. Carville K. Which dressing should I use? It all depends on the "TIMEING". Australian Family Physician. 2006;35:486-489.

8. Watret L, White R. Surgical wound management: the role of dressing. Nursing Standard. 2001;15:59-69. 
9. Field C, Kerstein M. Overview of wound healing in a moist environment. American Journal of Surgery. 1994;167(1):2-6.

10. Smith D, Thompson D, Bolton L, Hutchinson J. Microbiology and healing of the occluded skin-graft donor site. Plast Reconstr Surg. 1993;91(6):1094-1097.

11. Sezer A, Cevher E. Biopolymers as wound healing materials: challenges and new strategies. In: Pignatello R, ed. Biomaterials Applications for Nanomedicine. Rijeka, Croatia: InTect Publishing; 2011; Chapter 19.

12. Langenhove LV. Smart textiles for medicine and healthcare: Materials, Systems and Applications. Woodhead Publishing;2007.

13. Stashak, TS, Farstvedt, E, Othic, A. Update on wound dressings: indications and best use. Clinical Techniques in Equine Practice. 2004;3(2):148-163.

14. Menaker GM. Wound dressings at the turn of the millennium. Curr Probl Dermatol. 2001;29:86-89. doi: 10.1159/issn.1421-5721

15. Freyman M, Yannas V, Gibson J. Cellular materials as porous scaffolds for tissue engineering. Progress in Materials Science. 2001;46:273-282.

16. Reiter D. Methods and materials for wound management. Otolaryngol Head Neck Surg. 1994;110(6):550-556.

17. Lim K, Saliba L, Mctavish J, Raine J, Curtin P. Normal saline wound dressing-is it really normal? British Journal Of Plastic Surgery. 2000;53:42-45.

18. Still J, Glat P, Silverstain P, Griswold J, Mozingo D. The use of a collagen sponge/living cell composite material to treat donor sites in burn patients. Burns. 2003;29:837-841.

19. Muzarelli C, Muzarelli A. Natural and artificial chitosan-inorganic composites. Journal of Inorganic Chemistry. 2002;92:89-94.

20. Paul W, Sharma P. Chitosan and alginate wound dressing: a short review. Trends in Biomaterials And Artificial Organs. 2004;18:18-23.

21. Jakayumar J, Probaharan M, Sudheesh T, et al. Biomaterials based on Chitin and Chitosan in wound dressing applications. Biotechnology Advances. 
2011;29:322-337.

22. Mi L, Shyu S, Wu B, Lee T, Shyong Y, Huang N. Biomaterials. 2001;22(2):165173.

23. Loke K, Lau K, Yong L, Khor E, Sum K. Wound dressing with sustained antimicrobial capability. Biomed. Mater. 2000;53(1):8-17.

24. Hinrichs LJ, Lommen EJ, Wildevuur CRH, Feijen J. Fibraction and characterization of an asymmetric polyurethane membrane for use as a wound dressing. J Appl Biomater. 1992;3:287-303.

25. Denkbas EB, Ozturk E, Ozdem N, Kecec K, Agalar C. Norfloxacin-loaded chitosan sponges as wound dressing material. J Biomater Appl. 2004;18:291303.

26. Paul W, Sharma CP, Chitosan and alginate wound dressings: a short review, Trends Biomater. Artif Organs. 2004;18:18-23.

27. Jayakumar R, Sudhessh Kumar PT, Abhilash S, Manzoor K, Lakshmanan VK, Nair SV. The art, method, manner, process and system of chitosan hydrogel/nano zinc oxide membranes for wound dressing applications. U.S. Patent 1025/CHE/20102010. https://www.amrita.edu/publication/artmethod-manner-process-and-system-chitosan-hydrogel-nano-zinc-oxidemembranes-wound. Erişim tarihi: 20 Ocak 2020.

28. Muzzarelli RA, Mattioli-Belmonte M, Pugnaloni A, Biagini G. Chitosan Based Biomaterials. 1999;1(87):251-264.

29. Khan T, Peh K, Ch'ng H. Mechanical, bioadhesive strength and biological evaluations of chitosan films for wound dressing. J Pharm Pharmaceuf Sci. 2000;3(3):303-311.

30. Houacinea C, Yousaf S, Khan I, Khurana RK, Singh K. Potential of natural biomaterials in nano-scale drug delivery, Current Pharmaceutical Design. 2018;24:1-19. doi: 10.2174/1381612825666190118153057.

31. Knapp TR, Kaplan EN, Daniels JR. Injectable collagen for soft tissue augmentation. Plastic and Reconstructive Surgery. 1977;60:398-405. 
32. Hafemann B, Ensslen S, Erdmann C, et al. Use of a collagen/elastin-membrane for the tissue engineering of dermis. Burns. 1999;25:373-384.

33. Fernando S, Kim D, Nah JW, Jeon YJ. Advances in functionalizing fucoidans and alginates (bio)polymers by structural modifications: A review. Chemical Engineering Journal. 2019;355:33-48.

34. Thomas S. Alginate dressings in surgery and wound management-Part 1. Journal of Wound Care. 2000;9(2):56-60.

35. Winter GD. Formation of the scab and the rate of epithelization of superficial wounds in the skin of the young domestic pig. Nature. 1962;193:293-294.

36. Wang L, Khor E, Wee A, Lim LYJ. Chitosan-alginate PEC membrane as a wound dressing: Assessment of incisional wound healing. Biomed. Mater. Res. 2002;63:610-618.

37. Thomas A, Harding KG, Moore K. Alginates from wound dressings activate human macrophagesto secrete tumour necrosis factor-a. Biomaterials. 2000;21:1797-1802.

38. Balassa LL, Prudden JF. Applications of chitin and chitosan in wound healing acceleration. In Chitin, Chitosan and Related Enzymes, Academic Press, San Diego: 1984 .

39. Huang G, Chen J. Preparation and applications of hyaluronic acid and its derivatives, International Journal of Biological Macromolecules. 2019;125:478-484.

40. Saliba MJ. Heparin in the tratment of burns: a review. Burns. 2001;27:349-358.

41. Park SN, Lee HJ, Lee KH, Suh H. Biological characterization of edccrosslinked collagen-hyaluronic acid matrix in dermal tissue restoration. Biomaterials. 2003;24:1631-1641.

42. Miller RS, Steward DL, Tami TA, et al. The clinical effects of hyaluronic acid ester nasal dressing (Merogel) on intranasal wound healing after functional endoscopic sinus surgery. Otolaryngology-Head and Neck Surgery. 2003;128:862-869. 
43. Xu H, Ma L, Shi H, Gao C, Han C. Chitosan-Hyaluronic acid hybrid film as a novel wound dressing: in vitro and in vivo studies. Polymers for Advanced Technologies. 2007;18:869-875. doi: 10.1002/Pat.906.

44. Li B, Lu F, Wei X, Zhao R. Fucoidan: structure and bioactivity. Molecules. 2008;13:1671- 1695. doi:10.3390/molecules13081671.

45. Patankar MS, Oehninger S, Barnett T, Williams RL, Clark GF. A revised structure for fucoidan may explain some of its biological activities. Journal of Biological Chemistry. 1993;268:21770-21776.

46. O'Leary R, Rerek M, Wood EJ. Fucoidan modulates the effect of transforming growth factor (TGF)-beta1 on fibroblast proliferation and wound repopulation in in vitro models of dermal wound repair. Biological and Pharmaceutical Bulletin. 2004;27:266-270.

47. Sezer AD, Akbuğa J. Comparison on in vitro characterization of fucospheres and chitosan microspheres encapsulated plasmid DNA (pGM-CSF): formulation design and release characteristics. AAPS Pharm Sci Tech. 2009;10:1193-1199.

48. Dobashi K, Nishino T, Fujihara M. Isolation and preliminary characterization of fucose-containing sulfated polysaccharides with blood-anticoagulant activity from seaweed hizikia fusiforme. Carbohydr. Res. 1989;194:315-320.

49. Li B, Xin JW, Sun JL, Xu SY. Structural investigation of a fucoidan containing a fucose-free core from the brown seaweed hizikia fusiforme. Carbohydr. Res. 2006;341:1135-1146.

50. Pietramaggiori G, Yang HJ, Scherer SS, et al. Effects of poly-N-acetyl glucosamine (pGlcNAc) patch on woundhealing in $\mathrm{db} / \mathrm{db}$ Mouse. Journal of Trauma. 2008;64:803-808.

51. Varghase M, Balin A, Carter D, Caldwell D. Local environment of chronic wounds under synthetic dressings. Arch Dermatol. 1986;122(1):52-57.

52. Trumble DR, McGregor WE, Magovern JA. Validation of a bone analog modelfor studies of sternal closure. Annals of Thoracic Surgery. 2002;74:739745 . 
53. Hanna JR, Giacopelli JA. A review of wound healing and wound dressing products. The Journal of Foot and Ankle Surgery. 1997;36(1):2-14.

54. Choate CS, Wound dressings: a comparison of classes and their principles of use. J Am Podiatr Med Assoc. 1994;84(9):463-469.

55. Leipziger LS, Glushko V, Dibernardo B, et al. Dermal wound repair: role of collagen matrix implants and synthetic polymer dressing. J Am Acad Dermatol. 1985;12(2):409-419.

56. Olcay H, Kocak ED, Ylldı Z. Sustainability in polyurethane synthesis and biobased polyurethanes. Sustainability in the Textile and Apparel Industries. 2020;139-156.

57. Qin Y. Advanced wound dressings. J. Textile Institute. 2001;92(1):127-138.

58. Tart Group. Proplast. http://www.tart.cz/proplast-en/.Erişim tarihi 25 Aralık 2019.

59. Şenyuva C, Yücel A, Erdamar S, Çetinkale O, Seradjmir M, Özdemir C. The fate of alloplastic materials placed under a burn scar: an experimental study. Burns. 1997;23:484-489.

60. Karagöz MH, Seven Ş. Synthesis, characterization of (p-Tolyl Methyl Methacrylate) polymer and investigation of thermal properties. BEU Journal of Science. 2019;8(3):806-815.

61. Nakabayashi N. Dental biomaterials and the healing of dental tissue. Biomaterials. 2003;24:2437-2439.

62. Araújo L, Addor F, Campos PM. Use of silicon for skin and hair care: an approach of chemical forms available and efficacy. An Bras Dermatol. 2016;91(3):331-335. doi: 10.1590/abd1806-4841.20163986

63. O’Donovan DA, Mehdi SY, Eadie PA. The role of mepitel silicone net dressings in the managment of fingertip injuries in children. Journal of Hand Surgery. 1999;24:727-730.

64. Kerckhove E, Stappaerts K, Boeckx W, et al. Silicones in the rehabilitation of burns: a review and overview. Burns. 2001;27:205-214. 
65. Bugman P, Taylor S, Gyger D, et al. A silicone-coated nylon dressing reduces healing time in burned paediatric patients in comparison with standard sulfadiazine treatment: a prospective randomized trial. Burns. 1998;24:609612.

66. Uner-Bahar D, Işıldak I. Diabetic pressure ulcer treatment methods and maggot therapy. Tamap Journal of Engineering. 2019;103:1-12. doi: 10.29371/2019.3.103

67. King C. Changing attitudes toward maggot debridement therapy in wound treatment: a review and discussion. Journal of Wound Care. 2020;29 (Sup2c):S28-S34.

68. Mulder GD, Altman M, Seeley JE, et al. Prospective randomized study of the efficacy of hydrogel, hydrocolloid, and saline solution-moistened dressings on the management pressure ulcers. Wound Repair and Regeneration. 1993;1(4):213-218. doi: 10.1046/j.1524-475x.1993.10406.x 